\title{
The Control of Panicle Blight Bacterial Pathogen on Rice Seeds Through In Vitro Treatments
}

\author{
IRDA SAFNI*, UCI UTARI, MARYANI CYCCU TOBING \& LISNAWITA
}

\author{
Department of Agrotechnology, Faculty of Agriculture, Universitas Sumatera Utara, Padang Bulan, Medan, \\ 20155 Indonesia \\ *Corresponding author: irda@usu.ac.id \\ Received: 2 September 2020 Accepted: 18 December $2020 \quad$ Published: 31 December 2020
}

\begin{abstract}
Burkholderia glumae is a seed-borne pathogen of rice known to cause bacterial panicle blight disease. The lack of effective control methods makes seed treatment the alternative management approach. The aim of this research was to determine an effective seed treatments technique, using liquid smoke, clove oil, hot water and copper hydroxide fungicide treatment against bacteria $B$. glumae. The experiment used a complete randomized design with five treatments and three replications, including control, liquid smoke, clove oil, hot water, and copper hydroxide fungicide. The results showed the propensity for all treatments to reduce bacterial populations on rice seeds, while liquid smoke, clove oil, and fungicide did not reduce vigour and viability. Application of copper hydroxide fungicide $77 \%$ at concentration of $5 \%$ was recommended as the best treatment to control the bacterial pathogen.
\end{abstract}

Keywords: Burkholderia glumae, clove oil, copper hydroxide fungicide, hot water, liquid smoke, rice

Copyright: This is an open access article distributed under the terms of the CC-BY-NC-SA (Creative Commons Attribution-NonCommercial-ShareAlike 4.0 International License) which permits unrestricted use, distribution, and reproduction in any medium, for non-commercial purposes, provided the original work of the author(s) is properly cited.

\section{INTRODUCTION}

Rice has been an important staple food crop for over half of the world's population, including Indonesia (Ishaq et al., 2017). However, extreme weather conditions in the form of floods, droughts and the outbreak of pests and diseases have been affecting the crop productivity (Lamichhane et al., 2015). In Indonesia, Burkholderia glumae Urakami et al. (1994) is the important causal bacterial pathogen of rice panicle blight disease or bacterial grain rot disease, causing severe infection, and reducing the rice yield up to $75 \%$ (Trung et al. 1993). Recently, the occurrence of panicle blight disease has been reported in several locations, including West, Central and East Java (Wiyono et al., 2017), as well as South Sulawesi (Baharuddin et al., 2017) and North Sumatra (Hasibuan et al., 2018). According to the Minister of Agriculture, Republic of Indonesia, B. glumae is categorized as an A2 quarantine plant pest, which is impossible to remove from the seeds through quarantine treatments (Quarantine Agriculture, 2015). Since the potential for seed-borne pathogens dispersal via seed trade is high, the use of clean seed is recommended as an initial management approach to control the rice panicle blight disease
(Suryani, 2017). For example, dipping in liquid smoke (a natural product made from condensation or pyrolysis of materials containing lignin, cellulose, hemicellulose and other carbon compounds), clove oil as well as hot water treatment, in order to reduce or eliminate the pathogens (Taylor \& Dye, 1976; Zagory \& Parmeter, 1984; Milus, 1997; Light \& van Staden, 2004; Situmeang, 2013; Belmar et al., 2014; Achrom, 2015; Spadoro et al., 2017; Aisyah et al., 2018).

This study was aimed at testing the potential of several seed-treatment methods, including liquid smoke, clove oil, and hot water, to control $B$. glumae on rice seeds.

\section{MATERIALS AND METHODS}

This study was conducted in the Laboratory of Plant Disease, Faculty of Agriculture, Universitas Sumatera Utara, Indonesia from May to October 2018.

Bacterial isolate of $B$. glumae (IRC PRC) was obtained from the collection at Laboratory of Plant Disease, Faculty of Agriculture, Universitas 
Sumatera Utara, which was confirmed by the previous study (Hasibuan et al., 2018), cultured on King's B medium, and incubated at $37{ }^{\circ} \mathrm{C}$ for $48 \mathrm{~h}$. The bacterial suspension in sterile distilled water was measured using a spectrophotometer in order to attain $10^{8} \mathrm{cfu} / \mathrm{ml}(\mathrm{OD} 0.5, \lambda=600 \mathrm{~nm}$ ). Conversely, the rice seeds were surface sterilized using $\mathrm{NaOCl}$ for 5 minutes, washed with sterile distilled water, and air-dried on sterile filter papers, followed by introduction into the bacterial suspension $\left(10^{8} \mathrm{cfu} / \mathrm{ml}\right)$ and agitation for $4 \mathrm{~h}$ at room temperature. Then, the inoculated seeds were air-dried in a laminar air flow cabinet for 45 minutes and left overnight (a minimum of 15 hours) before the treatments.

All inoculated seeds (100 seeds per treatment) were treated with the following treatments for 10 minutes:

- Sterile distilled water as control,

- liquid smoke [5\% and 7\%, (v/v)],

- clove oil [2\% and 5\%, (v/v)],

- hot water $\left(50{ }^{\circ} \mathrm{C}\right.$ and $\left.60{ }^{\circ} \mathrm{C}\right)$,

- Copper hydroxide fungicide $77 \%$ [2\% and $5 \%,(\mathrm{v} / \mathrm{v})]$.

The concentration and temperature for each treatment were selected on the basis of previous studies (Tung \& Serrano, 2011; Situmeang, 2013; Achrom, 2015; Hoerussalam et al., 2017)

The bacterial count was subsequently determined by dipping the seeds in phosphatebuffered saline (PBS) solution, and ground to attain $80 \%$ crushed samples. Then, the samples were suspended in $20 \mathrm{ml} \mathrm{NaCl}$ for $1 \mathrm{~h}$ at room temperature and agitated for $2 \mathrm{~h}$. Next, the suspensions were subjected to a 10-fold dilution series, plated on King's B medium, and incubated at $37{ }^{\circ} \mathrm{C}$ for $48 \mathrm{~h}$. The bacterial colonies formed were counted.

After the seeds were treated, the seeds were germinated and assessed for seed vigour and viability. The seed vigour was assessed by evaluating the percentage of healthy seedlings grown five days after planting according to Eq. (1).

$\mathrm{VI}=\frac{\Sigma \text { NS } 5 \text { dap }}{\Sigma \text { seeds planted }} \times 100 \%$

Note:

VI : Vigour Index; NS: normal seedlings; dap: day after planting
Seed viability assessment involved the evaluation of total healthy seedlings percentage 5 day- and 14 day-after planting according to Eq. (2).

$$
\mathrm{VI}=\frac{\Sigma \text { NS } 5 \text { dap }+\Sigma \text { NS } 14 \text { dap }}{\Sigma \text { seeds planted }} \times 100 \%
$$

Note:

VI : Vigour Index; NS: normal seedlings; dap: day after planting

(Sutopo, 2004)

The data obtained were evaluated using Analysis of Variance for non-factorial Completed Block Design with three replications and Duncan's Multiple Range Test with SPSS Software to ascertain the possibility of treatments significantly affecting other parameters.

\section{RESULTS AND DISCUSSION}

The bacterial count were reduced after the treatments compared to the initial values recorded $\left(10^{8} \mathrm{cfu} / \mathrm{ml}\right)$, after a $48 \mathrm{~h}$ incubation (Table 1$)$. All treatments were able to reduce bacterial population by up to $99 \%$, as compared to the initial bacterial suspension concentration. Furthermore, all treatments significantly reduced the B. glumae bacterial count when compared to the control treatment. The higher concentration in all treatments resulted lesser bacterial count as compared to the lower concentrations. Therefore, the higher concentrations of each treatment was associated with the visibly reduced bacterial colonies, where fungicide at the concentration of $5 \%$, together with the two concentrations of liquid smoke demonstrated the most significant effect.

The best seed vigour ( $95.57 \%$ and $94.53 \%$ ) was observed with fungicide, at the respective concentration of $2 \%$ and $5 \%$, which was not different from the control and as well as from the liquid smoke treatments (Table 2). Table 2 shows the outcome for clove oil and hot water treatments, which was not good, as $2 \%$ and $5 \%$ clove oil resulted in $<80 \%$ of seeds capable of normal growth, based on the Indonesian standard quality requirements, which is more than $90 \%$ (Directorate General of Food Crop, 1991). Furthermore, none of the seeds were germinated in hot water treatment (Table 2).

Although there was no significant difference with the conrol treatment, rice seed germination rate was as high as control treatment (>80\%) for the 
liquid smoke and fungicide treatments. Conversely, the germination rate was at $75.43 \%$ and $56.66 \%$, when treated with clove oil at the respective concentration of $5 \%$ and $2 \%$. The use of selected concentrations of clove oil were on the basis of previous studies (Kishore \& Pande, 2007; van der Wolf et al., 2008; Hoerussalam., 2017), which applied not more than $5 \%$ of clove oil concentration as seed treatment for various crops. However, the rice seeds became toxic and could not germinate when the seeds were treated by clove oil at concentration of $2 \%, 3 \%$ and $4 \%$. Also, $50{ }^{\circ} \mathrm{C}$ and $60{ }^{\circ} \mathrm{C}$ hot treatments were unsuitable alternatives, because almost all seeds were not germinated (Table 2). The rice seed germination with treatments as seen in Figure 1.

Copper hydroxide fungicide and liquid smoke were able to reduce the population of $B$. glumae in vitro. This was possibly due to the presence of active ingredients in the form of phenol compounds, organic acids, and also copper, which particularly inhibits bacterial growth by binding to and hindering the synthesis of proteins in bacterial cells (Aisyah et al., 2018). Therefore, errors are generated while reading the genetic codes, ultimately leading to bacterial cell death (Hikichi \& Egami, 1998). The liquid smoke treatment is applied to suppress several plant diseases, based on the effective antimicrobial (Lingbeck et al., 2014) antioxidant and antibacterial activities (Yang et al., 2016). The major antibacterial compounds

Table 1. Bacterial population on rice seeds infected by B. glumae after different treatments

\begin{tabular}{lc}
\hline \multicolumn{1}{c}{ Treatments } & $\begin{array}{c}\text { Bacterial population } \\
(\mathbf{c f u} / \mathbf{m l})\end{array}$ \\
\hline A0 (Control) & $5.04 \times 10^{8 \mathrm{a}}$ \\
A1 (Liquid smoke 5\%) & $3.26 \times 10^{3 \mathrm{e}}$ \\
A2 (Liquid smoke 7\%) & $3.16 \times 10^{3 \mathrm{e}}$ \\
A3 (Clove oil 2\%) & $4.69 \times 10^{3 \mathrm{~b}}$ \\
A4 (Clove oil 5\%) & $4.32 \times 10^{3 \mathrm{c}}$ \\
A5 (Hot water 50 $\mathrm{C})$ & $4.70 \times 10^{3 \mathrm{~b}}$ \\
A6 (Hot water 60 $\mathrm{C})$ & $4.32 \times 10^{3 \mathrm{c}}$ \\
A7 (Fungicide 2\%) & $3.89 \times 10^{3 \mathrm{~d}}$ \\
A8 (Fungicide 5\%) & $3.10 \times 10^{3 \mathrm{e}}$ \\
\hline
\end{tabular}

detected in liquid smoke include 2,6dimethoxyphenol (syringol, 29.54\%), 2methoxyphenol (guaiacol, 12.36\%), and 3,5dimethoxy-4-hydroxytoluene $(11.07 \%$ ) (Yang et al., 2016). In addition, there are also a great potential for application as an organic pesticide and herbicide (Payamara, 2011).

Liquid smoke confers a positive effect in seed germination and seedlings vigor on a wide range of plant species (Abdollahi, 2012; Flematti et al., 2011). These activities are possibly due to the chemical composition, including catechol, which has previously been used for promoting Nicotiana attenuata root growth (Wang et al., 2017).

This current study showed a bad performance for hot water as a seed treatment to promote germination, as the heat generated does not break dormancy, but causes damages, especially in the embryo, which inhibits seeds growth. The hot water treatment at $54{ }^{\circ} \mathrm{C}$ for 10 minutes caused retardation and reduction in wheat seed germination due to seed coat breakage (Tapke, 1923). Meanwhile, the introduction of hot water at $55^{\circ} \mathrm{C}$ for 25 minutes on tomato seeds infected by Clavibacter michiganensis. michiganensis (Smith) lead to a low germination rate of $52.22 \%$ (Nalis, 2015). This also occured after introducing corn seeds infected by Pantoea stewartii subsp. Stewartii to temperatures above $50{ }^{\circ} \mathrm{C}$ (Nalis, 2015).

Table 2. Post-treatment vigour and viability of rice seeds infected with B. glumae

\begin{tabular}{lcc}
\hline \multicolumn{1}{c}{ Treatments } & $\begin{array}{c}\text { Seed vigour } \\
(\%)\end{array}$ & $\begin{array}{c}\text { Seed viability } \\
(\%)\end{array}$ \\
\hline A0 (Control) & $89.35^{\mathrm{a}}$ & $93.40^{\mathrm{ab}}$ \\
A1 (Liquid smoke 5\%) & $90.86^{\mathrm{a}}$ & $95.88^{\mathrm{ab}}$ \\
A2 (Liquid smoke 7\%) & $87.63^{\mathrm{a}}$ & $88.21^{\mathrm{b}}$ \\
A3 (clove oil 2\%) & $30.52^{\mathrm{c}}$ & $56.66^{\mathrm{d}}$ \\
A4 (Clove oil 5\%) & $58.33^{\mathrm{b}}$ & $75.43^{\mathrm{c}}$ \\
A5 (Hot water 50 $\left.{ }^{\circ} \mathrm{C}\right)$ & $0.00^{\mathrm{d}}$ & $0.00^{\mathrm{e}}$ \\
A6 (Hot water 60 $\left.{ }^{\circ} \mathrm{C}\right)$ & $0.56^{\mathrm{d}}$ & $0.57^{\mathrm{e}}$ \\
A7 (Fungicide 2\%) & $95.57^{\mathrm{a}}$ & $96.96^{\mathrm{ab}}$ \\
A8 (Fungicide 5\%) & $94.53^{\mathrm{a}}$ & $99.14^{\mathrm{a}}$ \\
\hline
\end{tabular}




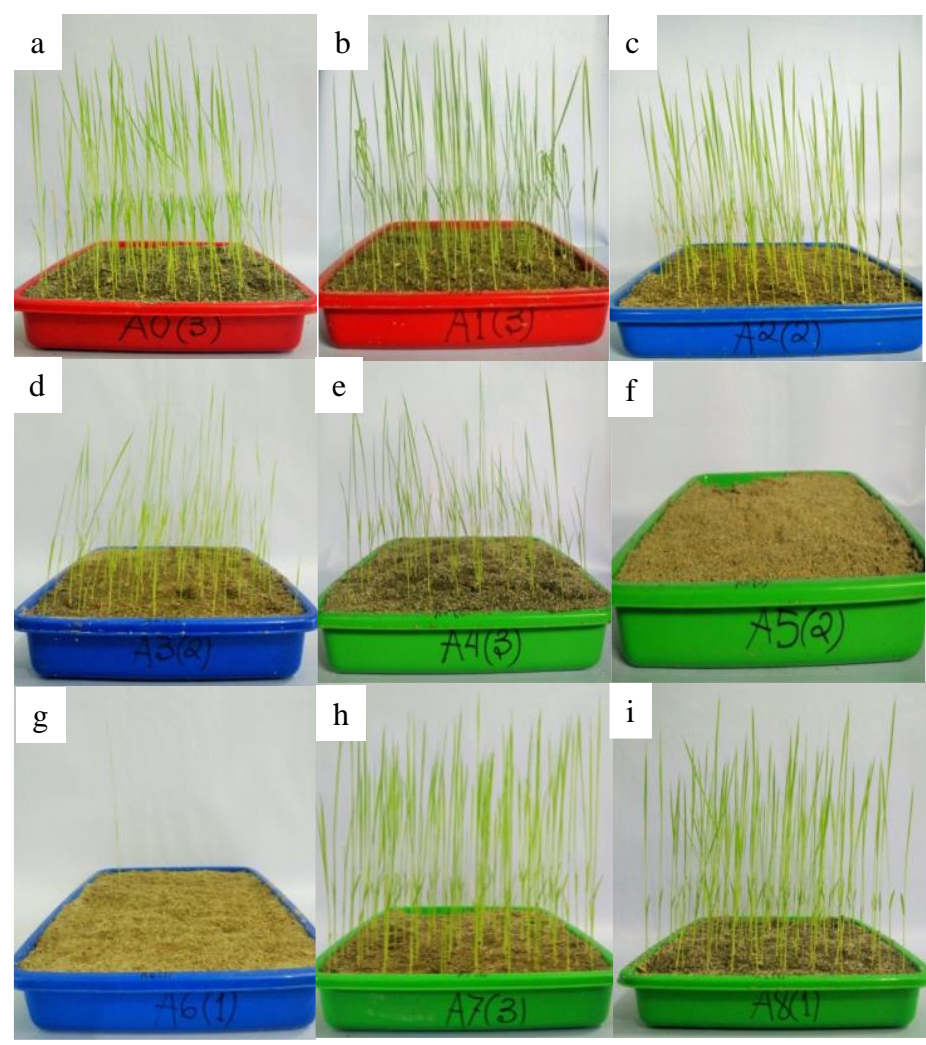

Figure 1. The germination of infected rice seeds with B. glumae after treated in the following treatments a) control; b) $5 \%$ liquid smoke; c) $7 \%$ liquid smoke; d) $2 \%$ clove oil; e) $5 \%$ clove oil; f) hot water at $50{ }^{\circ} \mathrm{C}$; g) hot water at $60{ }^{\circ} \mathrm{C}$; h) $2 \%$ fungicide; i) $5 \%$ fungicide

\section{CONCLUSION}

The application 5\% copper hydroxide fungicide $77 \%$ could control B. glumae population on rice seeds. This treatment was confirmed to confer a positive influence on the vigour and viability of seeds.

\section{ACKNOWLEDGEMENTS}

This work was supported by TALENTA grant from Universitas Sumatera Utara, Indonesia (Project No.339/UN5.2.3.1/PPM/KP-TALENTA USU /2018).

\section{REFERENCES}

Abdollahi, M.R. (2012). Effect of plant-derived smoke on germination, seedling vigour and growth of rapeseed (Brassica napus) under laboratory and greenhouse conditions. Seed Science \& Technology, 40(3): 437-442

Achrom, M. (2015). Perlakuan pencelupan asap cair untuk mengeleminasi bakteri Burkholderia glumae Kurita \& Tabei pada benih padi (Oryza sativa L.)
[Dipping treatment of liquid smoke to eliminate bacteri Burkholderia glumae Kurita and Tabei on rice (Oryza sativa L)]. Balai Uji Terap Teknik dan Metode Karantina Pertanian, Jawa Barat, Indonesia.

Aisyah, I., Sinaga, M.S., Nawangsih, A.S., Giyanto \& Pari G. (2018). Utilization of liquid smoke to suppress blood diseases on bananas and its effects on the plant growth. AGRIVITA Journal of Agricultural Sciences, 40(3): 453-460.

Baharuddin, Harniati R., Faisal, F., Yani, A., Suparmi, Hamid, H., Kuswinanti, T. \& Jahuddin R. (2017). Incidence of panicle blight disease (Burkholderia glumae) on rice in South Sulawesi. [Keberadaan penyakit busuk bulir (Burkholderia glumae) pada tanaman padi di Sulawesi Selatan]. In Pradana, M.G. \& Mubin, N. (eds.). Proceedings Simposium Nasional Fitopatologi Indonesia, Bogor, Indonesia.

Belmar, S.B., Kelsey, C.D., Gebremariam, T.A., Wamishe, Y.A. (2014). Seed management to control bacterial panicle blight of rice. AAES Research Series, 62: 82-94.

Directorate General of Food Crop - Directorate of Rice and Holticultural Production Sub Directorate of 
Quality Control and Seed Certification. 1991. Petunjuk Pengawas Benih [Directory of Seed Control]. Jakarta.

Flematti, G.R., Merritt, D.J., Piggott, M.J., Trengove, R.D., Smith, S.M., Dixon, K.W. \& Ghisalberti, E.L. (2011). Burning vegetation produces cyanohydrins that liberate cyanide and stimulate seed germination. Nature Communications, 2: 360. DOI: 10.1038 /ncomms1356

Hasanah, Y. (2017). Karakterisasi dan Pengendalian Burkholderia glumae Penyebab Penyakit Bacterial Grain Rot Menggunakan Teknologi Perlakuan Benih Kombinasi Perlakuan Fisik dan Kimia [Characterization and Control of Burkholderia glumae the Causal Pathogen of Bacterial Grain Rot Using Technology of Seed Treatment with Combination of Physichal and Chemical Treatments]. (Thesis), Universitas Brawijaya, Indonesia.

Hasibuan, M., Safni, I., Lisnawita \& Lubis, K. (2018). Morphological characterization of several strainsof the rice pathogenic bacterium Burkholderia glumae in North Sumatra. IOP Conf. Series:Earth and Environmental Science, 122: 012044.

Hikichi, Y. \& Egami, H. (1998). Control systems for bacterial grain rot of rice with oxolinic acid and seed selection with salt solution. Annals of the Phytopathological Society of Japan, 61(4): 405409.

Hoerussalam., Roesli, E.Z., Suparto, A. \& Lukman, R. (2017). Cara Efektif Untuk Menghilangkan Burkholderia glumae Dan Meningkatkan Kualitas Benih Padi. Seminar Nasional Kongres XXIV Perhimpunan Fitopatologi Indonesia, Kendari, Indonesia.

Ishaq, M., Rumiati, A.T., Permatasari, E.O. (2017). Analisis faktor - faktor yang mempengaruhi produksi padi di Provinsi Jawa Timur menggunakan regresi semiparametrik spline [Analysis factors effecting rice production in East Java using regression semiparametric spline]. Jurnal Sains dan Seni, 6(1): 2337-3520.

Kishore, G. K., Pande, S. \& Harish, S. (2007). Evaluation of essential oils and their components for broad-spectrum antifungal activity and control of late leaf spot and crown rot diseases in peanut. Plant Disease, 91: 375-379

Lamichhane, J.R., Barzman, L., Booij, K., Boonekamp, P., Desneux, N., Huber, L., Kudsk, P., Langrell, S.E.H., Ratnadass, A., Ricci, P., Sarah, J.L. \& Messéan, A. (2015). Robust cropping systems to tackle pests under climate change. A review. Agronomy for Sustainable Development, 35(2): 443 459.

Light, M.E. \& van Staden, J. (2004). The potential of smoke in seed technology. South African Journal of Botany, 70(1): 97-101.

Lingbeck, J.M., Cordero, P., O’Bryan, C.A., Johnson, M.G., Ricke, S.C. \& Crandall, P.G. (2014). Functionality of liquid smoke as an all-natural antimicrobial in food preservation. Meat Science, 97(2): 197-206.

Milus, E.A. \& Rothrock, C.S. (1997). Efficacy of bacterial seed treatments for controlling Pythium root rot of winter wheat. Plant Disease, 81: 180-184.

Nalis, S. (2015). Keefektifan perlakuan microwave, air panas, panas kering, dan bakterisida untuk menekan infeksi Pantoea stewartii subsp. stewartii pada benih jagung manis. [The efectivity of microwave, hot water, hot dry and bactericide to supress infection of Pantoea stewartii subsp. stewartii on sweetcorn seeds]. (Thesis), Institut Pertanian Bogor, Indonesia.

Payamara, J. (2011). Usage of wood vinegar as new organic substance. International Journal of ChemTech Research, 3(3): 1658-1662.

Quarantine Agriculture. (2015). Lampiran Keputusan Menteri Pertanian (Permentan) No 51/Permentan/KR010/9/2015 tentang Jenis-jenis Organisme Pengganggu Tumbuhan Karantina (OPTK) Kategori A1 dan A2. [Appendices of Ministry of Agriculture Injunction No 51/Permentan/KR010/9/2015 about different quarantine plant pests category A1 and A2]

Situmeang, M. (2013). Pengaruh Berbagai Perlakuan Untuk Mengendalikan Hawar Daun Bakteri (Xanthomonas oryzae $p v$. oryzae) Terbawa Benih Serta Meningkatkan Viabilitas dan Vigor Benih Padi (Oryza sativa L.). [Effect of Several Treatments to Control Seed-borne Bacterial Leaf Blight (Xanthomonas oryzae pv. oryzae) and to Improve Seed Vigor and Viability (Oryza sativa L). (Thesis), University of Gadjah Mada, Yogyakarta, Indonesia.

Spadaro, D., Herforth-Rahme, J. \& van der Wolf, J. (2017). Organic seed treatments of vegetables to prevent seedborne diseases. Acta Horticulture, 1164, 23-32. DOI: 10.17660/ActaHortic.2017.1164.3

Suryani L. (2017): Burkholderia glumae Penyebab Hawar pada Malai Padi. [Burkholderia glumae the causal pathogen of rice leaf blight]. Department of Agricultural Quarantine Class 1, Banjarmasin, Indonesia. 
Sutopo L. (2004): Teknologi Benih. [Seed Technology]. Rajawali Press, Jakarta, Indonesia.

Tapke, VF. (1923). Effects of the modified hot water treatment on germination, growth and yield of wheat. Journal of Agricultural Research, 28(1): 7997.

Taylor, J.D. \& Dye, D.W. (1976), Evaluation of streptomycin seed treatments for the control of bacterial blight of peas (Pseudomonas pisi Sackett 1916). New Zealand. Journal of Agricultural Research, 19(1): 91-95. DOI: 10.1080/ 00288233.1976 .10421050

Trung, H.M., Van, N.V., Vien, N.V., Lam, D.T. \& Lien, M. (1993). Occurrence of Rice Grain Rot Disease in Vietnam. International Rice Research Notes, 18(3): 30 .

Tung, L.D. \& Serrano, E.P. (2011). Effects of warm in breaking dormancy of rice seed. Omonrice, 18: 129136.

Urakami, T., Ito-Yoshida, C., Araki, H., Kijima, T., Suzuki, K. I., \& Komagata, K. (1994). Transfer of Pseudomonas plantarii and Pseudomonas glumae to Burkholderia as Burkholderia spp. and Description of Burkholderia vandii sp. International Journal of Systematic and Evolutionary Microbiology, 44(2): 235-245. van der Wolf, J.M., Bimbaum, Y., van der Zouwen, P.S. \& Groot, S.P.C. (2008). Disinfection of vegetable seed by treatment with essential oils, organic acids and plant extracts. Seed Science and Technolongy, 36: $76-88$.

Wang, M., Schuettner, M., Xu, S., Paetz, C., Wilder, J., Baldwin, I.T. \& Groten, K. (2017). Catechol, a major component of smoke, influences primary root growth and root hair elongation through reactive oxygen. New Phytologist, 213: 1755-1770.

Wiyono, S., Giyanto, Mutaqin, K.H., Hidayat, S.H. \& Supramana, W. (2017). Emerging Diseases pada Tanaman Pertanian: strategi dan opsi kebijakan pengendalian. In Pradana, M.G. \& Mubin, N. (eds.) Simposium Nasional Fitopatologi Bogor, Indonesia.

Yang, J.F., Yang, C.H., Liang, M.T., Gao, Z.J., Wu, Y.W. \& Chuang, L.Y. (2016). Chemical composition, antioxidant, and antibacterial activity of wood vinegar from Litchi chinensis. Molecules, 21(9): 1150. DOI: 10.3390/molecules21091150

Zagory, D., Parmeter, J.R., Jr. (1984). Fungitoxicity of smoke. Phytopathology, 74: 1027-1031. 